\title{
Factors Affecting Prenatal Care Utilization in East Wollega Zone, Oromia Regional State, Ethiopia
}

\author{
Tesfaye Regassa $^{1 *}$ and Gebi Agero ${ }^{2}$ \\ ${ }^{1}$ College of Medical and Health Sciences, Wollega University, Post Box No: 395, Nekemte, Ethiopia \\ ${ }^{2}$ School of Health Sciences, Adama University, Post Box Box: 396, Asella, Ethiopia
}

\section{Abstract}

The objective of the study was to identify factors affecting utilization of prenatal care and skilled birth attendant in East Wollega zone. Prenatal care and skilled birth attendant are crucial factor which affects the health and wellbeing of the mother and newborn and help the women to access skilled assistance, drugs, equipment and referral linkages. Even though, antenatal care coverage was relatively high in Oromia region (31.3\%), skilled birth attendant utilization was low (8\%). A total of 320 respondents were included in the study and data were collected using structured questionnaires. Data were first checked manually for completeness and then coded and entered into Epi Info version 6.04 and analyzed using SPSS version 20.0. Bivariate analyses between dependent and independent variable was performed using binary logistic regression separately. To control the effect of confounding variables, multiple logistic regressions were done. Multivariable logistic regression was used to identify predictors' of prenatal care. Statistical significance was determined through a 95\% confidence level. Women who attended secondary and above education were about fourteen times (AOR: 13.908, 95\% Cl: 1.177-164.311) more likely to utilize prenatal care. Partner's formal education was also associated with increased prenatal care (AOR: 1.915, 95\% Cl: 1.016-3.607). Partner occupation was also associated with prenatal care (AOR: $16.131,95 \% \mathrm{Cl}: 1.482-175.564)$. The study highlight that housewives were less likely to receive prenatal care from skilled professionals (AOR: $0.368,95 \% \mathrm{Cl}: 0.150-0.903)$. Another predictor of prenatal care was having functional communication materials (AOR: $2.145,95 \%$ $\mathrm{Cl}$ : 1.187-3.876). Longer waiting time at health institutions (AOR: $0.317,95 \% \mathrm{Cl}: 0.122$ $0.825)$ was significantly associated with prenatal care. Reported skill of health care providers (AOR: $2.406,95 \% \mathrm{Cl}: 1.051-5.509)$ were significantly associated with prenatal
\end{abstract} care.

Copyright@2014 STAR Journal. All Rights Reserved.
Article Information

Article History:

Received : 03-04-2014

Revised : 26-06-2014

Accepted : 27-06-2014

Keywords:

Prenatal care

Skilled birth attendant

East Wollega

${ }^{*}$ Corresponding Author:

Tesfaye Regassa

E-mail:

regassatesfaye@gmail.com

\section{INTRODUCTION}

Skilled health attendant is defined as an accredited health professional-such as a midwife, doctor or nursewho has been educated and trained to proficiency in the skills needed to manage normal pregnancies, childbirth and the immediate postnatal period, and in the identification, management and referral of complications in women and newborns. This definition excludes traditional birth attendants whether trained or not (WHO, 2006).

Skilled birth attendance serves as an indicator of progress towards improving maternal health (Baral et al., 2010). Skilled birth attendant is a crucial factor which affects the health and wellbeing of the mother and the newborn. It's usually a joyful event when women give birth to a baby she wants. However, birth is a critical time for the health of the mother and baby. Problems may arise during labour and delivery not treated properly and effectively can lead to ill health and even death of one or both of them (Sohail and Thomas, 2011; Ronsmans et al., 2003).
Reduction of maternal mortality is a global agenda. The maternal mortality ratio of Ethiopia was 676 deaths per 100,000 live births by 2011 compared to 673 deaths per 100,000 live births by 2005 . Skilled birth attendance is correlated with lower MMR. All countries should continue their efforts so that globally, by 2005 at least $80 \%$ of all births should be assisted by skilled attendants, by 2010, $85 \%$, and by 2015, 90\% (WHO 2000). However, the proportion of births with a skilled attendant is $8.1 \%$ in Oromia regional state. Therefore identifying the factors affecting prenatal care and skilled attendance for delivery is a priority area for interventions (EDHS, 2011; Sohail and Thomas, 2011; Ronsmans, et al., 2003; Prata et al., 2011).

The global consensus is that to improve maternal health and to reduce maternal mortality, pregnant women should be assisted by a competent health care professional who has the required equipment, drugs, supplies and an adequate referral system in place. Majority of mothers go through the process of unattended 
child birth and lack of prenatal care (Sohail and Thomas, 2011).

This agreement, signed by 179 country representatives, set a goal of $40 \%$ of all births to be assisted by a skilled attendant by 2005, with $50 \%$ coverage by 2010 and $60 \%$ by 2015 among the countries with very high maternal mortality. However, trends documenting the change in the proportion of births accompanied by prenatal care and skilled attendant over the last $15-20$ years offer no indication that adequate change is imminent. To improve maternal health rapidly in regions where births in the home without skilled birth attendants are common, governments and communitybased organizations could implement a cost-effective strategy (Prata et al. 2011; Adegoke et al., 2012).

Child birth is a risk producing event. Timely and adequate medical care for women who experience obstetric complication is an option for mitigating the risk. Women are encouraged to deliver their babies in health facilities (Lamina, 2011; Elizabeth et al., 2009; Laurel et al., 2007; Carolyn et al., 2007; Assfaw, 2010).

Significant improvement in maternal health could be achieved if skilled attendance is available to, and used by all women. To accomplish such a goal, targeting factors which affect prenatal care is essential. However, factors affecting prenatal care and skilled birth attendant were not well understood in East Wollega zone. Thus, the objective of study was to assess factors affecting prenatal care in East Wollega zone.

\section{METHODS AND MATERIALS}

\section{Study Area and Period}

The study was conducted in five districts (Sire, Jimma Arjo, Leqa Dullacha, Arjo Gudatu and Guto Gida) and Nekemte town of East Wollega Zone, Oromia regional state, Ethiopia from September to October 2013. East Wollega zone is one of the 17 zones of Oromia regional state with a population of $1,230,402 ; 615,641$ females. Eighty six percent of the populations live in rural areas $(1,061,120)$ (FDRE, 2008).

\section{Study Design and Study Population}

Cross sectional study was conducted in East Wollega Zone. Source population was all women aged 15-49 years. Study population was women in five districts and Nekemte town, in East Wollega Zone.

\section{Sample Size}

Sample size was calculated using EPI info software; by using antenatal care (ANC) coverage in Oromia region $(31.3 \%)$, with $95 \%$ confidence level and $5 \%$ marginal error. The calculated sample size was 320 .

\section{Data Collection Methods}

Structured questionnaire was initially prepared in English, translated to Afan Oromo, and back to English by different health professionals to check its consistency. It was then pre-tested on 5\% sample in an area that is not included in the study. Some skip patterns were then corrected and questions difficult to ask were rephrased.

\section{Data Collectors}

Bachelor degree holder nurse/midwife data collectors and master's holder supervisors were recruited. Two days training was given for data collectors and supervisors on objective, informed consent and techniques of interview. The structured questionnaire was discussed in detail going through every question and clarification was provided. All filled questionnaire was checked on spot for completeness, accuracy, clarity and consistency by the supervisors and the principal investigators and necessary corrections and changes was made.

\section{Data Analysis}

Data were first checked manually for completeness and then entered into Epi-Info version 6.04. After data entry and cleaning, the data were transferred to SPSS version 20.0 for analysis. Completeness and consistency of variables during data entry was checked using frequency distributions and cross tabulations. Percentages were calculated. Bivariate analysis between dependent and independent variables was performed separately using binary logistic regression. Multivariate analysis was used to remove effect of confounding variables. Statistical significance was determined through $95 \%$ confidence interval.

\section{Ethical Clearance}

Ethical approval was obtained from Ethical Review Board Committee, Wollega University. The purpose of the study was clearly explained for study participants and verbal consent was ensured.

\section{RESULTS}

\section{Socio-demographic Characteristics of Study Participants}

A total of 320 women were interviewed between September and October 2013 in East Wollega Zone. The mean age of the study participant was 26.12 years. Majority of the study subjects were Protestant Christians $(52.2 \%)$, Oromo by ethnicity $(89.7 \%)$ and currently married (95\%). About $58 \%$ of the respondents were farmers. Majority of the study participants had no formal education (195(60.9\%)). About 35\% of the respondents interviewed were from urban. The median monthly family income was 800 ETB. Concerning family size, majority of the study participants had 4-5 family size $142(44.4 \%)$ ) (Table 1).

\section{Prenatal Care Utilizations}

Majority of study participants had heard of ANC (88.4\%). About a quarter of them $(24.7 \%)$ had no antenatal care visit. About $17 \%$ reported pregnancy related complication (Table 2). The major complications during pregnancy were hemorrhage $24(7.5 \%)$ followed by hypertensive disorder of pregnancy $(8(2.6 \%))$ and abnormal vaginal discharge $(8(2.6 \%)$ ) (Figure 1$)$. It is indicated by figure that significant number of decisions to go for skilled birth attendant was made by husband and wife together but some other was made only by the husband (figure 2). The major types of non-skilled attendant in the study area were elderly women from neighbor (37\%), mother/mother in-law (35\%), traditional birth attendant (19\%). The main reasons for non-skilled birth attendant was labour were urgent to reach health facilities $90(28.1 \%)$ followed by lack of transport during labour 52(16.3\%) (Figure 4).

\section{Predictors of Prenatal Care}

Women who attended secondary and above education were about fourteen times (AOR: $13.908,95 \% \mathrm{Cl}$ : $1.177-$ 164.311) more likely to utilize prenatal care. Partner's with 
Table 1: Socio-demographic characteristics of study participants, East Wollega Zone, West Ethiopia $(n=320)$.

\begin{tabular}{|c|c|c|}
\hline \multicolumn{2}{|l|}{ Characteristics } & \multirow[b]{2}{*}{$\begin{array}{l}\text { Number (\%) } \\
19(5.9) \\
102(31.9) \\
111(34.7) \\
50(15.6) \\
38(11.9) \\
\end{array}$} \\
\hline Age & $\begin{array}{l}15-19 \\
20-24 \\
25-29 \\
30-34 \\
35-49 \\
\end{array}$ & \\
\hline Mean age( in years) $( \pm$ SD) & & $26.12( \pm 5.69)$ \\
\hline Educational status & $\begin{array}{l}\text { no formal education } \\
\text { Primary (1-8) } \\
\text { Secondary and above }\end{array}$ & $\begin{array}{l}195(60.9) \\
93(29.1) \\
32(10.0)\end{array}$ \\
\hline Educational status of husband & $\begin{array}{l}\text { no formal education } \\
\text { primary }(1-8) \\
\text { Secondary and above }\end{array}$ & $\begin{array}{l}106(33.1) \\
165(51.6) \\
49(15.3)\end{array}$ \\
\hline Marital status & $\begin{array}{l}\text { Married } \\
\text { never married /widowed/ divorce }\end{array}$ & $\begin{array}{l}305(95.3) \\
15(4.7)\end{array}$ \\
\hline Religion & $\begin{array}{l}\text { Orthodox } \\
\text { Muslim } \\
\text { Protestant } \\
\text { Catholic }\end{array}$ & $\begin{array}{l}100(31.3) \\
48(15.0) \\
167(52.2) \\
5(1.6)\end{array}$ \\
\hline Ethnicity & $\begin{array}{l}\text { Oromo } \\
\text { Others* }\end{array}$ & $\begin{array}{l}287(89.7) \\
33(10.3)\end{array}$ \\
\hline Occupation & $\begin{array}{l}\text { Farmer } \\
\text { Housewife } \\
\text { Employed (skilled) } \\
\text { Others }^{\star *}\end{array}$ & $\begin{array}{l}184(57.5) \\
71(22.2) \\
25(7.8) \\
40(12.5) \\
\end{array}$ \\
\hline Monthly income quintile & $\begin{array}{l}\text { Lowest } \\
\text { Second } \\
\text { Middle } \\
\text { Fourth } \\
\text { Highest }\end{array}$ & $\begin{array}{l}61(19.1) \\
65(20.3) \\
64(20.0) \\
58(18.1) \\
72(22.5) \\
\end{array}$ \\
\hline $\begin{array}{l}\text { Median family income (ETB) } \\
\text { Residence }\end{array}$ & $\begin{array}{l}\text { Urban } \\
\text { Rural }\end{array}$ & $\begin{array}{l}800 \\
111(34.7) \\
209(65.3)\end{array}$ \\
\hline Family size & $\begin{array}{l}1-3 \\
4-5 \\
6 \text { and above }\end{array}$ & $\begin{array}{l}72(22.5) \\
142(44.4) \\
106(33.1)\end{array}$ \\
\hline
\end{tabular}

${ }^{*}$ Amhara, Gurage, Tigire ${ }^{* *}$ House maid, private self-employment, merchant, daily laborer

Table 2: Prenatal care and obstetrics related factors of study participants, East Wollega zone, West Ethiopia

\begin{tabular}{|c|c|}
\hline Characteristics & Number (\%) \\
\hline Heard ANC & $\begin{array}{l}\mathbf{n}=\mathbf{3 2 0} \\
283(88.4) \\
37(11.6)\end{array}$ \\
\hline $\begin{array}{l}\text { Number of ANC received } \\
\text { No ANC received } \\
1-2 \\
3 \text { and above }\end{array}$ & $\begin{array}{l}\mathbf{n}=320 \\
79(24.7) \\
48(15.0) \\
193(60.3)\end{array}$ \\
\hline $\begin{array}{c}\text { Pregnancy related complications } \\
\text { Yes } \\
\text { No }\end{array}$ & $\begin{array}{l}\mathbf{n}=320 \\
53(16.6) \\
267(83.4)\end{array}$ \\
\hline $\begin{array}{l}\text { Pregnancy complications } \\
\text { Hemorrhage } \\
\text { Hypertensive disorder of pregnancy } \\
\text { Abnormal vaginal discharge } \\
\text { Others* }\end{array}$ & $\begin{array}{l}\mathbf{n}=53 \\
24(7.5) \\
8(2.6) \\
8(2.6) \\
13(4.1)\end{array}$ \\
\hline $\begin{array}{c}\text { Final decisions to go for skilled attendance } \\
\text { Together } \\
\text { husband } \\
\text { Self } \\
\text { Others }{ }^{\star *}\end{array}$ & $\begin{array}{l}\mathrm{n}=80 \\
48(15.0) \\
20(6.3) \\
10(3.1) \\
2(.6)\end{array}$ \\
\hline $\begin{array}{l}\text { Reasons for non-skilled birth attendant } \\
\text { Labour was urgent to reach health facilities } \\
\text { Lack of transport during labour } \\
\text { All my previous deliveries were at home } \\
\text { Home delivery is easy and convenient } \\
\text { Worries about cost in the hospital } \\
\text { Others ** }\end{array}$ & $\begin{array}{l}\mathrm{n}=240 \\
90(28.1) \\
52(16.3) \\
43(13.4) \\
37(11.6) \\
13(4.1) \\
15(4.7)\end{array}$ \\
\hline
\end{tabular}




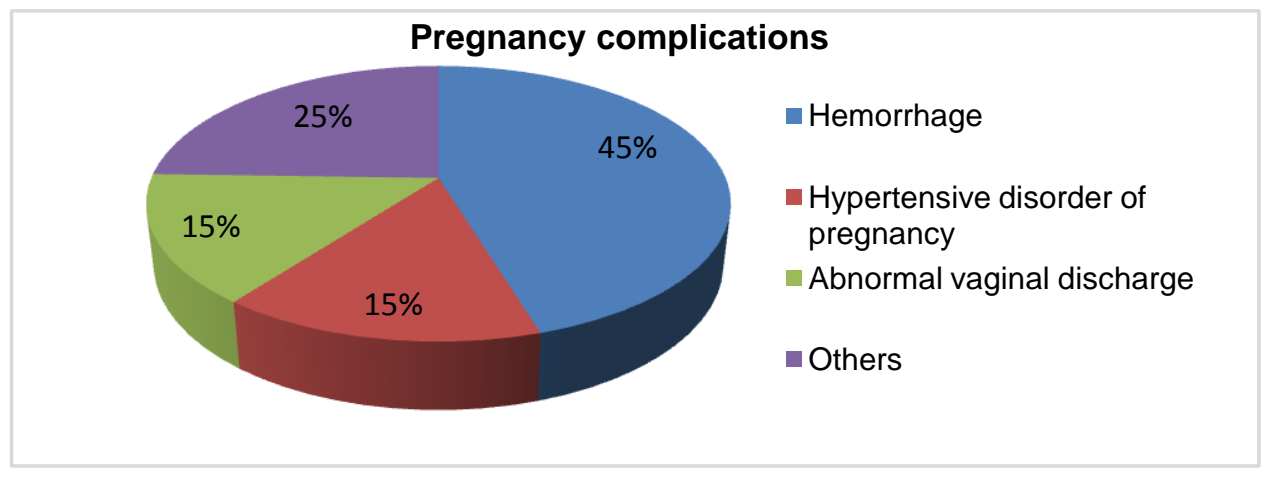

Figure 1: Pregnancy related complications among reproductive age women, East Wollega zone, West Ethiopia

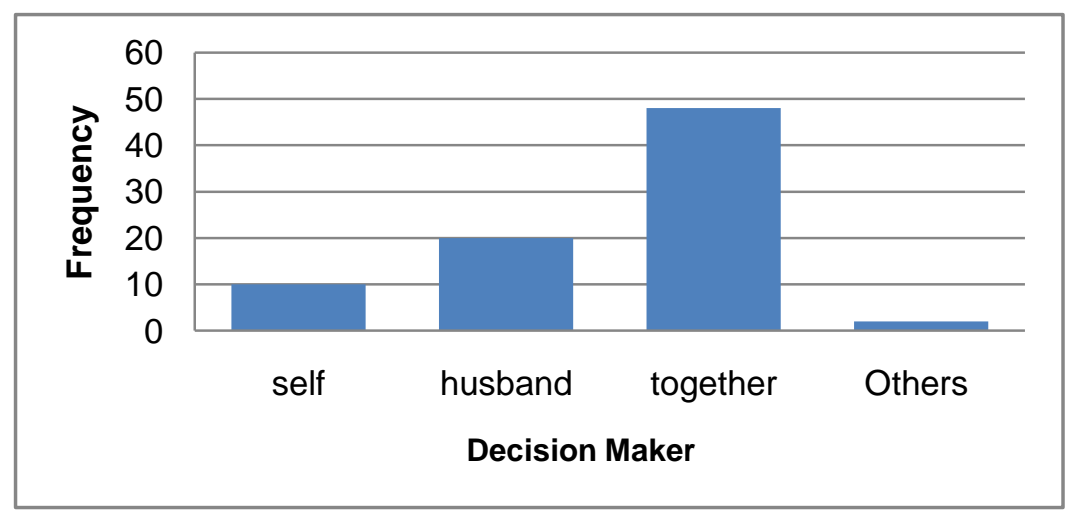

Figure 2: Final decision to go for skilled birth attendant among reproductive age women, East Wollega zone, West Ethiopia

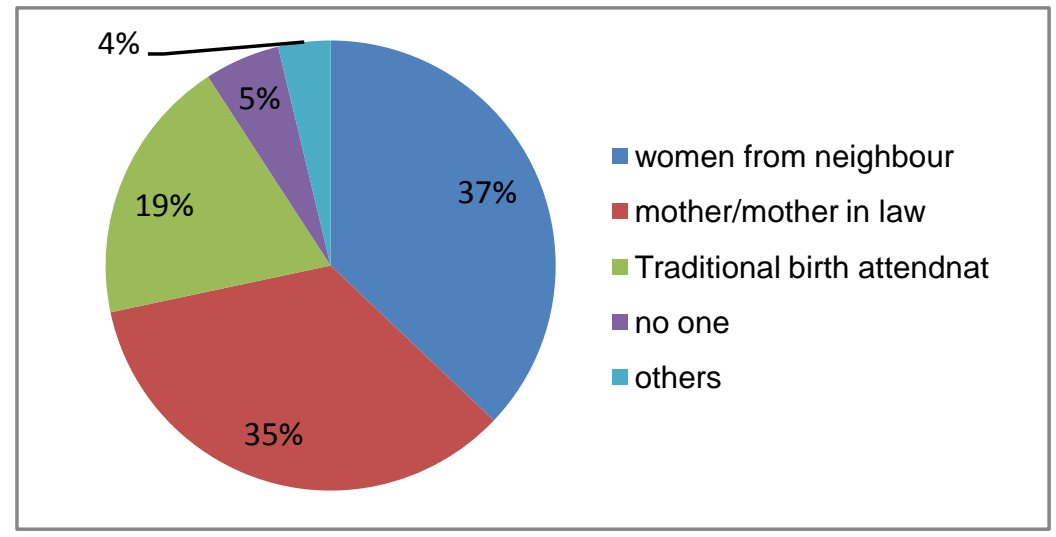

Figure 3: Types of non-skilled birth attendant in East Wollega zone, West Ethiopia.

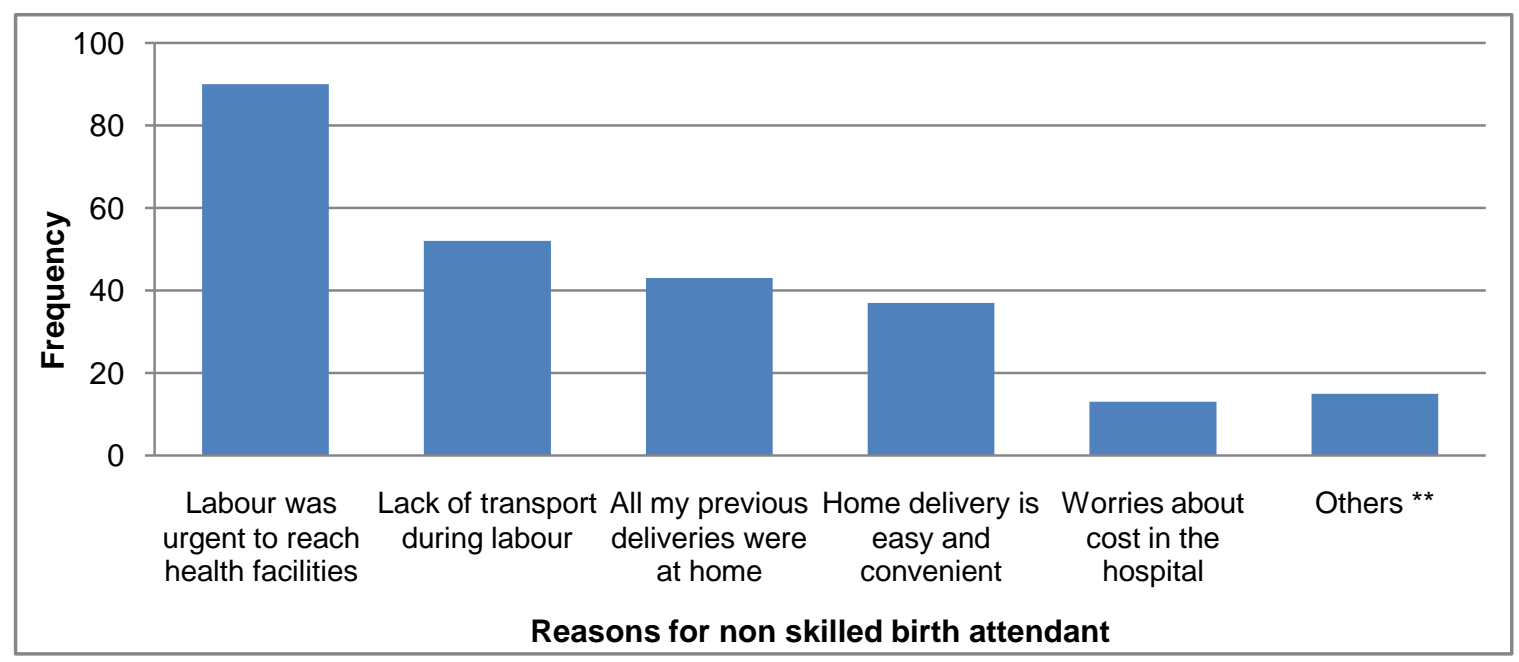

Figure 3: Reasons for non-skilled birth attendant in East Wollega zone, West Ethiopia. 
Tesfaye Regassa and Gebi Agero

formal education was also associated with increased prenatal care (AOR: 1.915, 95\% Cl: 1.016-3.607). Partner occupation was also associated with prenatal care (AOR: $16.131,95 \% \mathrm{Cl}: 1.482-175.564)$. The study highlight that housewives were less likely to receive prenatal care from skilled professionals (AOR: 0.368, 95\% Cl: 0.150-0.903). Another predictor of prenatal care was having functional
Sci. Technol. Arts Res. J., April-June 2014, 3(2): 148-154 communication materials (AOR: 2.145 , 95\% Cl: $1.187-$ 3.876). Longer waiting time at health institutions (AOR: $0.317,95 \% \mathrm{Cl}: 0.122-0.825)$ was significantly associated with prenatal care. Reported skill of health care providers (AOR: 2.406, 95\% Cl: 1.051-5.509) were significantly associated with prenatal care (Table 3).

Table 3: Unadjusted and adjusted odds ratios $(\mathrm{OR})$ and $95 \%$ confidence intervals $(\mathrm{Cl})$ of prenatal care utilization in East Wollega zone, West Ethiopia, September to October 2013.

\begin{tabular}{|c|c|c|c|c|c|}
\hline \multirow{2}{*}{ Variables } & \multirow{2}{*}{ Categories } & \multicolumn{2}{|c|}{$\begin{array}{c}\text { Antenatal care } \\
\text { utilization }\end{array}$} & \multicolumn{2}{|c|}{ OR(95\% Cl) } \\
\hline & & Yes (\%) & No (\%) & Crude & Adjusted \\
\hline \multirow{3}{*}{ Education level } & No formal education & $130(53.9)$ & $65(82.3)$ & 1 & 1 \\
\hline & Primary education & $80(33.2)$ & $13(16.5)$ & $3.077(1.594-5.938)$ & $2.747(1.206-6.258)$ \\
\hline & $\begin{array}{l}\text { Secondary and above } \\
\text { education }\end{array}$ & $31(12.9)$ & $1(1.3)$ & $15.500(2.070-116.083)$ & $13.908(1.177-164.311)$ \\
\hline \multirow{3}{*}{$\begin{array}{l}\text { Education status } \\
\text { of partner }\end{array}$} & No formal education & $66(27.4)$ & $40(50.6)$ & 1 & 1 \\
\hline & Primary education & $132(54.8)$ & $33(41.8)$ & $2.424(1.402-4.191)$ & $1.915(1.016-3.607)$ \\
\hline & Secondary and above & $43(17.8)$ & $6(7.6)$ & 4.343(1.696-11.120) & $0.306(.067-1.389)$ \\
\hline \multirow{4}{*}{ Occupation } & Farmer & $127(52.7)$ & $57(72.2)$ & 1 & 1 \\
\hline & Housewife & $53(22.0)$ & $18(22.8)$ & $1.322(0.711-2.455)$ & $0.368(0.150-0.903)$ \\
\hline & Skilled employee & $24(10.0)$ & $1(1.3)$ & $10.772(1.422-81.578)$ & $1.355(0.131-14.047)$ \\
\hline & Others * & $37(15.4)$ & $3(3.8)$ & $5.535(1.639-18.700)$ & $2.047(0.488-8.583)$ \\
\hline \multirow{4}{*}{$\begin{array}{l}\text { Occupation of } \\
\text { the partner }\end{array}$} & Farmer & 142(58.9) & $67(84.8)$ & 1 & \\
\hline & Skilled employee & $39(16.2)$ & $1(1.3)$ & $18.401(2.475-136.798)$ & $16.131(1.482-175.564)$ \\
\hline & Merchant & $26(10.8)$ & $5(6.3)$ & $2.454(.902-6.671)$ & $1.132(0.303-4.224)$ \\
\hline & Others ${ }^{\star *}$ & $34(14.1)$ & $6(7.6)$ & $2.674(1.071-6.677)$ & $1.754(0.590-5.211)$ \\
\hline \multirow{5}{*}{$\begin{array}{l}\text { Monthly income } \\
\text { quintile }\end{array}$} & Lowest & $39(16.2)$ & $22(27.8)$ & 1 & \\
\hline & Second & $47(19.5)$ & $18(22.8)$ & $1.473(0.693-3.130)$ & \\
\hline & Middle & $50(20.7)$ & $14(17.7)$ & $2.015(0.914-4.440)$ & \\
\hline & Fourth & $48(19.9)$ & $10(12.7)$ & $2.708(1.147-6.390)$ & \\
\hline & Highest & $57(23.7)$ & $15(19.0)$ & $2.144(0.990-4.641)$ & \\
\hline \multirow{2}{*}{ Residence } & Urban & $97(40.2)$ & $14(17.7)$ & $3.127(1.662-5.886)$ & \\
\hline & Rural & $144(59.8)$ & $65(82.3)$ & 1 & \\
\hline \multirow{3}{*}{$\begin{array}{l}\text { Possessing } \\
\text { Radio and/or TV }\end{array}$} & Yes & $166(68.9)$ & $33(41.8)$ & $3.085(1.827-5.209)$ & $2.145(1.187-3.876)$ \\
\hline & No & $75(31.1)$ & $46(58.2)$ & 1 & 1 \\
\hline & 1 & $83(34.4)$ & $20(25.3)$ & 1 & \\
\hline \multirow[t]{2}{*}{ Birth order } & $2-3$ & $100(41.5)$ & $30(38.0)$ & $0.803(0.425-1.518)$ & \\
\hline & 4 and more & $58(24.1)$ & $29(36.7)$ & $0.482(0.249-0.933)$ & \\
\hline \multirow{4}{*}{$\begin{array}{l}\text { Walking time to } \\
\text { reach health } \\
\text { institution }\end{array}$} & $<30$ minutes & $123(51.0)$ & $21(26.6)$ & 1 & \\
\hline & $31-60$ & $60(24.9)$ & $18(22.8)$ & $0.569(0.282-1.147)$ & \\
\hline & $61-120$ & $38(15.8)$ & $21(26.6)$ & $0.309(0.153-0.626)$ & \\
\hline & $\begin{array}{l}121 \text { and above } \\
\text { minutes }\end{array}$ & $20(8.3)$ & $19(24.1)$ & $0.180(0.082-0.392)$ & \\
\hline \multirow{4}{*}{$\begin{array}{l}\text { Waiting time at } \\
\text { health institution }\end{array}$} & $1-15$ & $103(42.7)$ & $25(31.6)$ & 1 & 1 \\
\hline & $16-30$ & $72(29.9)$ & $19(24.1)$ & $0.920(0.472-1.794)$ & $0.760(0.353-1.635)$ \\
\hline & $31-60$ & $41(17.0)$ & $17(21.5)$ & $0.585(0.286-1.196)$ & $0.427(0.184-0.993)$ \\
\hline & $>60$ minutes & $25(10.4)$ & $18(22.8)$ & $0.337(0.160-0.712)$ & $0.317(0.122-0.825)$ \\
\hline \multirow{3}{*}{$\begin{array}{l}\text { Number of health } \\
\text { care providers }\end{array}$} & Don't know & $66(27.4)$ & $34(43.0)$ & 1 & \\
\hline & $1-2$ & $135(56.0)$ & $39(49.4)$ & $1.783(1.033-3.079)$ & \\
\hline & Greater than two & $40(16.6)$ & $6(7.6)$ & $3.434(1.325-8.903)$ & \\
\hline \multirow{3}{*}{$\begin{array}{l}\text { Skill of health } \\
\text { care providers }\end{array}$} & High & $135(56.0)$ & $33(41.8)$ & $2.799(1.495-5.242)$ & $2.406(1.051-5.509)$ \\
\hline & Medium & 68(28.2) & $20(25.3)$ & $2.326(1.149-4.709)$ & $2.109(0.915-4.859)$ \\
\hline & Poor & $38(15.8)$ & $26(32.9)$ & 1 & 1 \\
\hline
\end{tabular}

${ }^{*}$ House maid, private self-employment, merchant, daily laborer and ${ }^{* \star}$ Unemployed, Daily Laborer, Student 


\section{DISCUSSION}

The proportion of women who delivered with the assistance of a skilled birth attendant and prenatal care is one of the indicators in meeting the fifth MDG (UNFPA). There was agreement, signed by 179 country representatives, set a goal of $40 \%$ of all births to be assisted by a skilled attendant by 2005 , with $50 \%$ coverage by 2010 and $60 \%$ by 2015 among countries with very high maternal mortality. However Oromia, skilled health professionals attend very few births (Mehari, 2013; Adegoke and Broek, 2009; Crowe et al. 2012; Adegoke et al., 2012).

In Ethiopia, it may be difficult to achieve the ICPD+5 target of $62 \%$ coverage with skilled attendance at birth by 2015 especially considering the current average of $10 \%$. However identifying the main predictors and challenges in the implementation of this strategy which if addressed will help progress towards the achievement (Adegoke, et al., 2012).

Education is a key factor in improving prenatal care, but it is challenge for study area where more than half of the women $(60.9 \%)$ had no formal education (EDHS 2011). Education is likely to enhance confidence and capabilities to make decisions regarding their own health.

Education of women had been found to influence the use of prenatal care. Women who attended secondary and above education were about fourteen times more likely to utilize prenatal care. The effect was more significant among women with at least secondary school education. The data is consistent with studies from Ghana (Arthur, 2012), migrants in Western (Boerleider, et al., 2013), Brazil (Coimbra et al., 2007), Nigeria (lyaniwura and Yussuf, 2009), Nepal (Joshi et al., 2014), Ethiopia (Tekelab and Berhanu, 2014). Thus, improving the education of mothers will contribute greatly to the use of maternal and prenatal services by women and thus help in reducing maternal and child mortality. Specifically, women should be encouraged to pursue education beyond the primary level as the study has found that women with higher levels of education tend to make adequate use of prenatal care.

Partner's education and occupation was also associated with increased prenatal care. Educational levels of the husbands also showed a similar effect on the receipt of ANC visits (Joshi et al., 2014; Tekelab and Berhanu, 2014). The study indicated that educating women and their husbands together resulted in women retaining more maternal health knowledge than if they attended alone, that educational strategies become more effective when men are incorporated.

The study highlight that housewives were less likely to receive prenatal care from skilled professionals. A welleducated and skilled woman may have a good job and earn more money, which improves economic access and reinforces the effect of adequate information.

Another predictor of prenatal care was functional communication materials like TV and/or radio. It may be possible that the less educated are not adequately informed about the services being offered freely and also about the adequate utilization for each pregnancy, hence it may be necessary to intensify the education on the use of maternal health care services probably through the mass media (radio, television) and the community announcements, especially in the rural centers where the use of mass media were not adequate.

Waiting longer time at health institutions was significantly associated with prenatal care. Clients conceived skill of health care providers was significantly associated with prenatal care. Health extension workers can support women groups through an action-learning cycle in which they can identify local prenatal problems and improve antenatal care utilization.

However, Ethiopian demographic and health survey indicated that in Oromia regional state $31 \%$ of women received ANC care but skilled birth attendant was 8\% (EDHS, 2011). It implies that in Ethiopia there are opportunities to improve skilled birth attendant including issues related to prenatal care. Limitation of the study was cross sectional studies are not able to establish temporal relationships.

\section{CONCLUSIONS}

The study identified predictors of prenatal care that are related to social factors such as respondents education, partner's education, occupation of partner; having access to functional communication materials. Therefore, improving women's education and partner education is very important to improve prenatal care utilization.

We recommended that there should be progress toward a health education program that enables more women to utilize prenatal care by targeting uneducated women, uneducated partner, housewife, communication materials, waiting time at health institutions. Transportation service for pregnant women at delivery has to be considered to increase low level of skilled birth attendant utilization.

\section{ACKNOWLEDGEMENTS}

The authors acknowledge Wollega University for funding this research project. It gives us a great honor to thank all study participants for their cooperation in providing the necessary information.

\section{REFERENCES}

Adegoke, A., Bettina Utz, S.E.M. and Broek, N.V.D. (2012). Skilled Birth Attendants: Who is Who? A Descriptive Study of Definitions and Roles from Nine Sub Saharan African Countries. PLoS ONE 7(7): e40220.

Adegoke, A. and Broek, N.V.D. (2009). Skilled birth attendance-lessons learnt. BJOG: An International Journal of Obstetrics and Gynaecology 116: 33-40.

Arthur, E. (2012). Wealth and antenatal care use: implications for maternal health care utilisation in Ghana. Health Economics Review 2:14.

Assfaw, Y.T. (2010). Determinants of Antenatal Care, Institutional Delivery and Skilled Birth Attendant Utilization in Samre Saharti District, Tigray, Ethiopia. Public Health $\mathrm{MPH}, 72$.

Baral, Y.R., Lyons, K., Skinner, J. and van Teijlingen, E.R. (2010). Determinants of skilled birth attendants for delivery in Nepal. Kathmandu University Medical Journal 8: $525-331$.

Boerleider, A. W., Wiegers, T. A., Manniën, J., Francke, A. L. and Devillé, W. L. (2013). Factors affecting the use of 


\section{Tesfaye Regassa and Gebi Agero}

prenatal care by non-western women in industrialized western countries: a systematic review. BMC Pregnancy and Childbirth 13:81.

Carolyn, J.T., Moses, K., Linda, M., David, M., Moses, M., Heiner, G. and Alison, M.E. (2007). Use of antenatal services and delivery care in Entebbe, Uganda: a community survey. BMC Pregnancy and Childbirth 7.

Coimbra, L.C., Figueiredo, F.P., Silva, A.A. M., Barbieri, M. A., Bettio, H., Caldas, A.J.M., Mochel, E.G. and Ribeiro, V.S. (2007). Inadequate utilization of prenatal care in two Brazilian birth cohorts. Brazilian Journal of Medical and Biological Research 40: 1195-1202.

Crowe, S., Utley, M., Costello, A. and Page, C. (2012). How many births in sub-Saharan Africa and South Asia will not be attended by a skilled birth attendant between 2011 and 2015? . BMC Pregnancy and Childbirth 12: 4.

EDHS (2011) Ethiopian Demographic and Health Survey. (pp. 82), Addis Ababa, Ethiopia: CSA.

Elizabeth, F., Alison, B., Bondan, S. and Wayan, S. (2009). Do Women Increase Their Use of Reproductive Health Care When It Becomes More Available? Evidence from Indonesia. Studies in Family Planning 40: 27-38.

FDRE, C. (2008). Summary and statistical report of the 2007 population and Housing census. popualtion size by age and sex. Addis Ababa. www.ecastats.uneca.org/ aicmd/ Portals/0/Cen2007_firstdraft.pdf

lyaniwura, C.A. and Yussuf, Q. (2009). Utilization of Antenatal care and Delivery services in Sagamu, South Western Nigeria. African Journal of Reproductive Health 13: 111-122.

Joshi, C., Torvaldsen, S., Hodgson, R. and Hayen, A. (2014). Factors associated with the use and quality of antenatal care in Nepal: a population-based study using the demographic and health survey data. BMC Pregnancy and Childbirth 14: 94.
Sci. Technol. Arts Res. J., April-June 2014, 3(2): 148-154

Lamina, M.A. (2011). A Survey of Home Delivery and Newborn Care Practices among Women in a Suburban Area ofWestern Nigeria. ISRN Obstetrics and Gynecology Article ID 983542.

Laurel, H., Cynthia, S., Krystyna, M., Asri, A., Endang, A. and Carine, R. (2007). Did the strategy of skilled attendance at birth reach the poor in Indonesia? Bulletin of the World Health Organization 85: 774-782.

Mehari, A.M. (2013). Levels and Determinants of Use of Institutional Delivery Care Services among Women of Childbearing Age in Ethiopia: Analysis of EDHS 2000 and 2005 Data. In I. International (Ed.). Calverton, Maryland, USA: DHS Working Papers.

Prata, N., Passano, P., Rowen, T., Bell, S., Walsh, J. and Potts, M. (2011). Where There Are (Few) Skilled Birth Attendants. Journal of Health, Population and Nutrition 29: 81-91.

Ronsmans, C., Etard, J. F., Walraven, G., Høj, L., Dumont, A., Bernis, L. d. and Kodio, B. (2003). Maternal mortality and access to obstetric services in West Africa. Tropical Medicine and International Health 8: 940-948.

Sohail, A. and Thomas, W. C. (2011). Determinants of institutional delivery in rural Jhang, Pakistan. Agha and Carton International Journal for Equity in Health 10.

Tekelab, T. and Berhanu, B. (2014). Factors Associated with Late Initiation of Antenatal Care among Pregnant Women Attending Antenatal Clinic at Public Health Centers in Kembata Tembaro Zone, Southern Ethiopia. Science Technology and Arts Research Journal 3(1): 108-115.

WHO (2000). Reproductive health indicators for global monitoring;report of interagency meeting. In: R.H.A. Research and F.A.C. health (Eds.). Geneva, WHO.

WHO (2006). Reproductive Health Indicators Guidelines for their generation, interpretation and analysis for global monitoring. In: R. H. A. Research (Ed.). Geneva, WHO. 